\title{
O Cuidado da Casa Comum é nossa responsabilidade
}

Pe. Josafá Carlos de Siqueira SJ - Reitor da PUC-Rio

Mesmo com certas tendências atuais de movimentos nacionalistas, onde os estados nacionais tendem a compreender a si mesmo dentro de suas fronteiras geográficas, fechando-se para outros povos, não podemos negar que o processo de globalização reforçou a consciência de que o planeta Terra é a nossa casa comum. O espaço planetário tão pluriverso, social e ambientalmente, possui inter-relações e cadeias climáticas e biológicas, cujas alterações locais repercutem no global e vice versa.

As tradições religiosas da humanidade, de maneira particular a judaico-cristã, se fundamentam num Deus Criador da casa comum, onde todas as criaturas espelham o amor e a bondade divina, cabendo ao ser humano, criado a imagem e semelhança de Deus, a missão de cuidar e administrar com responsabilidade da grande casa planetária, não como dono e proprietário, mas como guardião deste patrimônio criacional. Em outras épocas e eras geológicas, a evolução da vida no planeta aconteceu com surgimento e desaparecimento de muitos seres vivos, condicionados por razões climáticas e biológicas, antes do aparecimento do ser humano sobre a face da terra. No entanto, a partir do nosso surgimento, coube-nos a tarefa de zelar, cuidar e administrar as grandezas e as fragilidades das múltiplas formas de vida que integram a casa comum. Assim, o tema da guardianidade passa a ter cada vez mais importância, sobretudo nos nossos dias onde os processos de alteração e modificação de nossos biomas e ecossistemas têm afetado o clima e as inter-relações biológicas, gerando consequências sérias para o planeta, o meio ambiente e a sociedade humana. Diante deste desafio é que as instituições civis e religiosas, nacionais e internacionais, têm procurado refletir, discutir e apresentar propostas na linha de uma casa comum socialmente mais justa e fraterna, e ambientalmente mais solidária e sustentável.

Além da importância dos estudos e pesquisas científicas que têm contribuído para minimizar os impactos e apresentar soluções para o equilíbrio da casa comum, várias espiritualidades surgiram ao longo da história, incorporando princípios ecológicos que integram a relação do ser humano com Deus e com a Criação. Embora o conceito de Criação seja tratado muitas vezes como a natureza, o primeiro tem um sentido mais teológico, pois supõe um Criador que dá sentido a todas as coisas. Tomando por exemplo a tradição da espiritualidade inaciana dos jesuítas, podemos verificar que a Criação deve fazer parte permanente da memória, pois dela recebemos inúmeros benefícios 
(Exercícios Espirituais n.234). A Criação também deve ser vista como um dos lugares que Deus habita nas criaturas, agindo e trabalhando por nós nos elementos, nas plantas, nos animais etc (Exercícios Espirituais n.235 e 236). Assim, minha missão diante da Criação consiste em colaborar com o Criador, para que as criaturas possam continuar existindo e glorificando a ELE, não permitindo que a obra criacional seja desrespeitada, destruída e mutilada, como nos lembra o Papa Francisco na Laudato Si'.

Além dos princípios inspiradores que aparecem na Teologia da Criação e nas diversas espiritualidades da Igreja, nos últimos anos alguns pontífices têm enfatizado a temática de guardiões da Criação. João Paulo II, em Redemptor Hominis, 1979, afirma: "Era vontade do Criador que o homem tenha um contato com a natureza como dono e guardião, inteligente e nobre, e não como explorador e destruidor". Bento XVI, em Caritas in Veritate, 2009 diz: "A natureza está à nossa disposição não como um monte de lixo espalhado por acaso, mas como um dom do Criador que traçou os seus ordenamentos intrínsecos dos quais o homem há de tirar as devidas orientações para guardar e cultivar". O Papa Francisco, na homilia da missa de inauguração do seu pontificado, 13 de março de 2013, foi enfático ao dizer: "A vocação de guardião da Criação não diz respeito apenas a nós cristãos, mas tem uma dimensão antecedente, que é simplesmente humana e diz respeito a todos: é guardar a Criação inteira, a beleza da Criação, como diz no Livro dos Gênesis e nos mostrou São Francisco de Assis: é ter respeito por todas as criaturas de Deus e pelo meio ambiente onde vivemos...".

Hoje, com a publicação da Encíclica ecológica Laudato Si', e diante da grave crise ambiental em que vivemos, a nossa missão de guardiões da Criação passa a ser um compromisso fundamental, tanto para os crentes, como também para os não crentes, como afirmou o Papa Francisco nos objetivos da Encíclica. Segundo ele, "Viver a vocação de guardiões da obra do Deus não é algo de opcional nem um aspecto secundário da experiência cristã, mas parte essencial de uma existência virtuosa" (Laudato Si', n.217).

Tendo diante dos olhos o que está acontecendo em nossa casa comum, poluições, mudanças climáticas, cultura do descarte e do desperdício, escassez dos recursos hídricos, perda da biodiversidade, deterioração da qualidade de vida humana, desigualdade social etc, cresce o nosso compromisso e a missão de sermos guardiões da casa comum. Assim com São Francisco de Assis, que percebeu que a grande missão de sua época era reconhecer a paternidade comum que permite a todos, humanos e não humanos, de serem chamados de irmãos e irmãs, pois temos o mesmo Pai Criador. Hoje, no contexto atual, somos chamados a proteger e cuidar de todas as formas de vida 
existentes no planeta onde habitamos, optando preferencialmente por aquelas mais ameaçadas e vulneráveis, tanto do ponto de vista antropológico, como também daqueles seres vivos que ecologicamente se encontram em posição de risco de extinção. Ser hoje uma pessoa religiosa engajada é uma tarefa desafiadora, pois temos que atuar diante dos vários desafios, mudando mentes, convertendo corações e realizando gestos significativos em prol de toda a obra da Criação. Assim, a dimensão humana e ambiental deve fazer parte de nossa missão, pois ambas as realidades estão profundamente unidas naquilo que a Laudato Si' chama de Ecologia Integral. O guardião de nosso tempo deve saber cuidar do humano e do meio ambiente, pois todas as criaturas estão interligadas, e precisamos uns dos outros para viver e exercer com responsabilidade aquilo que o Pai Criador colocou em nossas mãos, não para excluir e extinguir, mas para cuidar, respeitar e reconhecer o valor de cada ser existente, independente de sua utilidade. Como Jesus Cristo, que viveu em plena harmonia com a criação, nós hoje somos chamados a viver a nossa vocação de guardiões numa sociedade preocupada com a justiça social e ambiental, lutando para superar tudo aquilo que compromete a dignidade do ser humano e de toda a criação, preservando o meio ambiente que é um bem coletivo e patrimônio de toda a humanidade, buscando permanentemente a conversão ecológica, e procurando fazer no dia a dia de nossa casa, família, escola e comunidade, gestos que nos ajudam a cuidar do planeta Terra, nossa casa comum.

Na Laudato Si' o Papa Francisco nos chama a atenção sobre os pontos que fazem parte de nossa responsabilidade para com a casa comum. Vejamos alguns deles. $O$ primeiro é a importância de resgatar a visão integradora onde todas as coisas estão interligadas, e por fazermos parte e estarmos incluídos na Criação, na natureza, não estamos separados como sendo uma mera moldura da nossa vida. É por isso que quando se fala em crises, saibamos que não há duas crises separadas, uma ambiental e outra social, mas uma única e complexa crise socioambiental (L.S. 139). O segundo, temos que aproveitar o clima de sensibilidade que existe hoje pelo meio ambiente e o cuidado com a natureza, pois cresce a preocupação pelo que está acontecendo com o nosso planeta (L.S.19). O urgente desafio de proteger a nossa casa comum inclui a preocupação de unir toda família humana na busca de um desenvolvimento sustentável e integral, pois sabemos que as coisas podem mudar, e os jovens exigem uma mudança (L.S.13). O terceiro ponto são as questões ambientais que nos preocupam, com repercussão na vida social, como a biodiversidade e os recursos hídricos. Quanto à biodiversidade, temos aspectos negativos e positivos. Negativos pelo desaparecimento 
anual de milhares de espécies, sendo que a maioria delas se extingue por razões ligadas com alguma atividade humana. A Laudato Si' nos recorda que por nossa causa milhares de espécies já não darão glória a Deus com as suas existências, nem poderão comunicarnos a sua própria mensagem. Nós não temos o direito de fazer isso (L.S.33). Os nossos oceanos estão ameaçados (L.S.40) e muitos recifes de corais do mundo já são estéreis ou encontram-se em estado contínuo de declínio (L.S.41); a perda das florestas e demais ecossistemas implica na perda de espécies (L.S.32). De maneira positiva, temos que reconhecer o valor da fauna e da flora, independente de suas utilidades, sabendo que por estarem interligadas, devemos reconhecer com carinho e admiração o valor de cada uma (L.S.42). As diferentes espécies contêm genes que podem ser recursos chaves para resolver no futuro muitas necessidades humanas e vários problemas ambientais (L.S.32). No que se refere aos recursos hídricos, esta deve ser também uma de nossas preocupações, pois a água potável e limpa é indispensável para a vida humana e a sustentação de nossos ecossistemas (L.S.28). A escassez deste recurso cresce em várias partes do mundo, afetando milhares de pessoas e aumentando o custo dos alimentos e de outros produtos (L.S.31), sobretudo pelos altos índices de desperdício na agricultura, na indústria e no consumo humano (L.S.30), além da má qualidade da água que provoca muitas doenças entre os pobres (L.S.29). Temos que tomar cuidado com a privatização desse recurso que é um bem de caráter universal, não permitindo que o mesmo se torne apenas uma mercadoria sujeita às leis do mercado (L.S.30). O quarto ponto está relacionado com as coisas que podemos e devemos criticar, a saber: A visão fragmentada entre natureza, sociedade e ciência (L.S. 110); o individualismo desordenado (L.S.119), sem ética e sem sentido social e ambiental (L.S.217); o relativismo prático que trata as pessoas e a natureza como meros objetos (L.S.123); a cultura do descarte social e ambiental (L.S.22); a exploração excessiva dos ecossistemas e a extinção de espécies (L.S.33,36-38); a corrupção que esconde o verdadeiro impacto ambiental de projetos em troca de favores (L.S.182); a mutilação da obra do Criador (L.S.89) e a pretensão humana de ser dono absoluto de todas as criaturas (LS.67); o ritmo de consumo e desperdício que supera as possibilidades do planeta e o torna insustentável (L.S.161); as atitudes que dificultam os caminhos de solução, como a indiferença, a resignação acomodada e a confiança cega apenas nas soluções técnicas (L.S.14). O quinto e último ponto se refere às coisas que podemos fazer para mudar como: viver a vocação de guardiões da obra de Deus como parte essencial de nossa vida (L.S.217); estabelecer o diálogo entre as diferentes religiões visando o cuidado com a natureza, a defesa dos pobres e a 
construção de uma rede de respeito e fraternidade (L.S.201); buscar a conversão ecológica que supõe: o reconhecimento do mundo como um dom recebido do amor de Deus Pai e a consciência amorosa de não estar separado das outras criaturas (L.S.220); buscar a simplicidade de vida, que permite saborear as coisas pequenas, agradecer as possibilidades que a vida nos oferece, sem apegarmos ao que temos, nem nos entristecermos por aquilo que não possuímos (L.S.222); apoiar e viver a educação ambiental a partir de pequenas ações diárias que estão ao nosso alcance como: evitar o uso do plástico e o consumo exagerado de papel, reduzir o consumo de água, reciclar o lixo, cuidar dos outros seres vivos, fazer uso dos transportes públicos ou compartilhar o veículo com outras pessoas, plantar árvores, apagar as luzes desnecessárias (L.S.211). O importante é ter a consciência de que estes pequenos gestos e ações são fundamentais para a sustentabilidade do planeta, deixando para as gerações futuras uma casa comum com mais dignidade social e ambiental.

Finalmente, a responsabilidade de ser guardião da casa comum passa também pela ética, ajudando-nos a mudar os hábitos insustentáveis e criar novos hábitos socialmente mais justos e ecologicamente mais corretos e equilibrados. Nesta perspectiva, somos estimulados a repensar e reformular alguns dos valores éticos que acompanham os nossos processos educativos, a saber: uma educação menos consumista, onde o desperdício deve ser evitado, diminuindo os abismos existentes entre riqueza e pobreza; uma educação que possa combater a cultura do descarte de pessoas e dos recursos da Terra; uma educação que conscientize as pessoas sobre os efeitos e consequências das mudanças climáticas, preparando-as para a convivência dos processos mitigatórios e adaptativos; uma educação que promova a defesa da biodiversidade, onde os biomas, os ecossistemas e as espécies se tornam a cada dia vulneráveis e ameaçadas pelas ações antrópicas; uma educação que combata o relativismo prático, não permitindo que as pessoas sejam tratadas como objetos, gerando muitas formas de exploração do ser humano, e tirando-lhes a dignidade de filhos de Deus; uma educação aberta para um novo estilo de vida com maior simplicidade; uma educação que favoreça o diálogo inter-religioso, sobretudo num mundo onde "a maior parte dos habitantes do planeta declara-se crente, e isto deveria levar as religiões a estabelecerem diálogo entre si, visando ao cuidado da natureza, à defesa dos pobres, à construção de uma rede de respeito e fraternidade" (Laudato Si', n.201); uma educação que resgate a visão sistêmica de mundo, permitindo perceber as relações intrínsecas entre as coisas que fazem parte da casa comum, naquilo que a Laudato Si' denomina de Ecologia 
Integral; uma educação que enfatize os princípios do bem comum, como a interculturalidade, a justiça distributiva, a cultura da paz, os direitos humanos, o respeito pelas diferenças e o cuidado com a criação; uma educação que se abra para os novos paradigmas, onde a música, a poesia, a contemplação, o silêncio e a oração são fundamentais no processo de humanização e espiritualização da pessoa humana; finalmente, uma educação que ajude na mudança e conversão dos contravalores que destroem o ser humano, robotizam a existência, criam isolamentos e vazios, devassam a natureza e acabam por não deixar um legado para as gerações futuras que merecem receber um mundo melhor e mais sustentável. O Papa Francisco nos recorda que "a educação será ineficaz e os seus esforços estéreis, se não se preocupar também em difundir um novo modelo relativo ao ser humano, à vida, à solidariedade e à relação com a natureza" (Laudato Si', n.215).

Neste ano de 2017, onde a Igreja Católica lança mais uma Campanha da Fraternidade cujo tema é sobre os biomas brasileiros e defesa da vida, possamos unir as diferentes religiões, e também os não crentes, numa rede de reflexão e busca de soluções em prol da relação intrínseca entre os nossos biomas e as diferentes culturas humanas que estão relacionadas com a amazônia, o cerrado, a mata atlântica, a caatinga, o pantanal e os pampas sulinos. A fraternidade une as diferenças, supera as barreiras e nos torna mais solidários com as questões sociais e ambientais.

\section{REFERÊNCIAS BIBLIOGRÁFICAS:}

FRANCISCO, Papa. Carta Encíclica Laudato Si - sobre o cuidado da casa comum. São Paulo: Paulinas, 2015.

MURAD, A. \& TAVARES, S.S. Cuidar da casa comum. São Paulo: Paulinas, 2016.

SIQUEIRA, J.C. de. Laudato Si': um presente para o planeta. Rio de janeiro: Editora PUC, 2016. 